\title{
Özel Gereksinimli Çocukların Okul Öncesi Eğitiminde Karşılaşılan Sorunlar
}

\section{Problems Encountered in Preschool Education of Children with Special Needs}

https://doi.org/10.52105/temelegitim.11.1

\author{
Mehmet ÖZDOĞRU1,
}

https://orcid.org/0000-0002-3853-8389

Geliş Tarihi/Received: 25/12/2020 Kabul Tarihi/Accepted: 01/07/2021 Yayın Tarihi/Published: 15/07/2021

Özet:

$\mathrm{Bu}$ araştırmanın amacı özel eğitim gereksinimli çocukların okul öncesi eğitiminde öğretmenlerin karşılaştıkları sorunları ve bu sorunlarla başa çıkma stratejilerini öğretmen görüşlerine göre incelemektir. Araştırma nitel yöntemle gerçekleştirilmiştir. Araştırmada fenomenolojik desene başvurulmuştur. Katılımcılar özel eğitim anaokullarında görev yapan 17 öğretmenden oluşmaktadır. Araştırma verilerinin toplanması aşamasında yarı yapılandırılmış görüşme formundan yararlanılmıştır. Ulaşılan veriler içerik analizi tekniğinden yararlanılarak analiz edilmiştir. Araştırma sonucunda özel eğitim gereksinimli çocukların okul öncesi eğitiminde karşılaşılan sorunlar velilerden kaynaklı sorunlar, okulun fiziki imkânlarından kaynaklı sorunlar ve öğretim sürecinde karşılaşılan sorunlar olmak üzere üç temada toplanmıştır. Öğretmenlerin bu sorunlarla başa çıkma stratejileri ise etkili iletişim kurma, öz bakım eğitimine daha fazla zaman ayırma, dikkat sürelerini göz önünde bulundurarak etkinlik sürelerini kısa tutma ve etkinlikleri çeşitlendirme, meslektaşlarla iş birliği yapma, istenmeyen davranışların nedenini tespit etme ve müdahalede bulunma, gerekli materyalleri imkânlar dâhilinde kendi hazırlama, aile eğitimi faaliyetleri düzenleme ve uyum süreçlerini uzun tutma olarak tespit edilmiştir. Araştırma bulgularına dayanarak; özel eğitim gereksinimli çocuğa sahip ailelere eğitim süreçlerindeki rol ve sorumlulukları hakkında bilinçlendirme faaliyetleri yapılması, özel eğitim gereksinimli çocukların engel durumlarına uygun ihtiyaç duyulan ders materyallerinin bakanlıkça temin edilmesi, okul bahçeleri ve sınıflarının okul öncesi eğitime uygun olacak şekilde planlanarak yapılması, mevcut fiziki mekânların iyileştirilmesi önerilebilir.

Anahtar Kelimeler: Özel Eğitim, Okul Öncesi, Özel Gereksinimli Çocuk

\begin{abstract}
:
The aim of this research is to examine the problems faced by teachers in the preschool education of children with special educational needs and the strategies for coping with these problems according to the views of the teachers. The research was carried out by qualitative method. Phenomenological design was used in the study. Participants consist of 17 teachers working in special education kindergartens. A semi-structured interview form was used in the collection of research data. The obtained data were analyzed using the content analysis technique. As a result of the research, the problems encountered in the pre-school education of children with special education needs were gathered under three themes: problems caused by parents, problems arising from the physical facilities of the school and problems encountered in the teaching process. The strategies of teachers to cope with these problems are to communicate effectively, to spend more time on self-care training, to keep activity durations short and diversify activities by considering attention spans, to cooperate with colleagues, to identify the cause of undesirable behaviors and to intervene, to use the necessary materials within the possibilities. Self-preparation, organizing family education activities and keeping the adaptation processes long. Based on the research findings; It can be recommended to raise awareness about the roles and responsibilities of families with children with special education needs, to provide the necessary course materials suitable for the disability of children with special education needs, by the ministry, to plan school gardens and classrooms in accordance with pre-school education, and to improve existing physical spaces.
\end{abstract}

Keywords: Special Education, Pre-School, Special Needs Child,

1E-posta: mehmetozdogru26@gmail.com 


\section{Giriş}

Okul öncesi eğitim ülkelerin eğitim politikalarının oluşturulmasında gün geçtikçe öncelikle üzerinde durulan konuların başında yer almaktadır. Okul öncesi eğitim gelişmiş ülkelerin birçoğunda zorunlu tutulmakla birlikte gelişmekte olan ülkelerde de gittikçe önem kazanmaktadır (Ridzwan \& Mokhsein, 2017). Ülkemizde ise okul öncesi eğitimin yaygınlaştırımasına yönelik önemli adımlar atılmakla birlikte şu an için zorunlu bir eğitim kademesi değildir.

Okul öncesi dönemde çocukları gelişimsel yönden alanlarını desteklemek, çocuğun ilgisi ve gereksinimine cevap veren ortamlar yaratabilmek ailenin yalnız başarabileceği bir durum değildir. İşte bu sebeple okul öncesi eğitim kurumları ailelere çocuğun gelişim özellikleri, ilgileri, gereksinimleri ve bunlara uygun çevre hazırlama konusunda ailelere destek olmalı, ailede sunulamayan ortamlar ise kurumda oluşturulmalıdır (Dinç vd., 2012).

Okul öncesi dönem, çocuğun doğumundan itibaren ilkokula başladığı döneme kadar geçen yılları kapsayan, çocukların yaşamlarında önemli bir rolü olan; zihinsel, bedensel, sosyal-duygusal ve dil gelişimlerinin büyük bir bölümünün tamamlandığı, kişiliğinin şekillendiği ve sürekli değişimin olduğu bir süreçtir. Çocuğun yüksek düzeyde öğrenme potansiyeline sahip olduğu bir dönem olarak da görülmektedir (Başal, 2013).

Son yıllarda eğitimle ilgili yapılan araştırmalar okul öncesi eğitimin bireyin sonraki eğitim hayatlarına önemli katkı sağladığını göstermektedir. Okul öncesi eğitim çocuğun sosyalleşmesini sağlamakla birlikte duygusal gelişiminin de desteklenmesini sağlayarak sonraki dönemlerde bireyin üretkenliğini ve verimliliğini arttırmaktadır (Kern \& Friedman, 2009). Okul öncesi eğitimi, çocuğun ileri akademik yaşamını etkileyen büyük bir öneme sahiptir. Çocuğun burada kazandığı edinimler ve başarılar ilerideki başarılarını tetikler ve teşvik eder. Okul öncesi eğitimin amacı; çocukların bedensel, zihinsel, duygusal gelişimini ve iyi alışkanlıklar kazanmasını, onların ilköğretime hazırlanmasını sağlamaktır. Erken müdahalenin amacı fiziksel, bilişsel, duygusal ve biyolojik olarak ya da çevresel risk faktörleri açısından dezavantajlı olan küçük çocukların sınırlı kaynaklarını en aza indirmek ya da engellenmektir (Akçamete vd., 2012).

Normal gelişim gösteren çocukların yanı sıra özel gereksinimli çocuklar için de okul öncesi eğitim oldukça önemlidir. Okul öncesi eğitimde, özel gereksinimli çocuğun tüm gelişim alanlarındaki gelişimini hızlandırmak, okul yaşına geldiğinde genel eğitim ortamlarından yararlanma olasılığını artırmak ve ailelerinin yaşadığı duygusal ve toplumsal sorunları azaltmak amaçlanmaktadır (Akçamete, 1998). Okul öncesi eğitim, özel gereksinimli çocukların gereksinimlerini de dikkate alarak, tüm çocuklara öğrenme ve ilkokula hazırlık konusunda eşit fırsatlar sunmayı amaçlar (Gürkan, 2013).

Özel gereksinim ihtiyacı olan çocukların bulundukları çevrede bağımsız, kendi ihtiyacını karşılayabilecek bireyler olması, onların gereksinim durumlarının belirlenerek bu gereksinimleriyle uyumlu eğitim ortamlarında verilecek hizmetleriyle mümkün olacaktır (Şahbaz \& Kalay, 2010). Özel eğitime ihtiyaç duyan çocukların yetersizlik durumları birbirlerinden farklılık gösterdiğinden sınıflandırma yapılarak eğitim verilmektedir. Özel Eğitim Hizmetleri Yönetmeliği'nde özel gereksinimli bireyler; "zihin yetersizliği olan birey, birden fazla yetersizliği olan birey, dikkat eksikliği ve hiperaktivite bozukluğu olan birey, dil ve konuşma güçlüğü olan birey, duygusal ve davranış bozukluğu olan birey, görme yetersizliği olan birey, işitme yetersizliği olan birey, ortopedik yetersizliği olan birey, otistik birey, özel öğrenme güçlüğü olan birey, süreğen hastalığı olan birey, üstün yetenekli birey" olarak sınıflandııılmıştır (Vuran, 2013).

Özel gereksinimli bireylere verilecek eğitim hizmeti bireyin gereksinim durumu göz önünde bulundurularak alanında uzmanlaşmış kişilerce verilmelidir (Cavkaytar, 2019). Okul öncesinde özel eğitimle ilgili çalışmalar, 0-6 yaş arasındaki çeşitli yetersiz çocuklarla, velilerine uzmanlar tarafından sunulan eğitimsel faaliyetlerden oluşmaktadır. Bu eğitim faaliyeti; çocuğun yaşı, gelişimlerine göre klinik, ev, okul gibi farklı mekânlarda verilebilir (Başal, 2003).

Türkiye'de özel gereksinimli çocuklara 573 sayılı Özel Eğitim Hakkında Kanun Hükmünde Kararname (1997) ve Özel Eğitim Hizmetleri Yönetmeliği (2006) çerçevesinde hizmet sunulmaktadır. Özel gereksinimli çocukların bir kısmı kaynaştırma uygulamalarının yürütüldüğü okul öncesi kurumlara 
akranları ile birlikte devam etmekte, bir kısmı ise okul öncesi özel eğitim kurumlarında özel gereksinimli akranları ile birlikte eğitim almaktadırlar. Yine bazı özel gereksinimli çocuklar sadece bireysel özel eğitim hizmeti alırken, bazıları hem özel eğitim hem de okul öncesi eğitim hizmeti almak için aynı anda iki kurumdan hizmet almaya devam etmekte, bazıları ise iki hizmete de ulaşamamaktadır (Bakkaloğlu, 2013).

MEB özel eğitim ve rehberlik hizmetleri yönetmenliğinde özel eğitim hizmetleri, 0-36 aylık çocuklar için erken çocukluk dönemi hizmetleri, ailenin bilgilendirilmesini ve desteklenmesini de içerecek şekilde yürütülür ve 37 aydan gün alan ve 69 ayını doldurmayan özel eğitim ihtiyacı olan çocuklar için okul öncesi eğitim zorunludur. Çocukların gelişimi ve özellikleri dikkate alınarak okulöncesinde eğitim süresi bir yıl daha uzatılabilir.

Özel gereksinimli çocukların okul öncesi eğitiminde birtakım sorunlarla karşılaşılmaktadır. Bu sorunların başında özel gereksinimli çocukların okul öncesi eğitim kurumlarına kabulünün çeşitli nedenlerle engellenmesi gelmektedir (Praisner, 2003). Başka bir sorun da bu bireylerin okula uyum ve öz bakım becerilerinde zorluklar yaşamasıdır (Barrafato, 1998). Demir \& Kale'ye (2019) göre özel eğitim gereksinimli öğrencilerin öğretim sürecinde birtakım sorunlarla karşılaşılmakta, özellikle uyum sorunları sıklıkla yaşanmaktadır.

Özel eğitim gereksinimli çocukların okul öncesi eğitiminde karşılaşılan sorunların tespit edilerek çözüm önerileri sunulması etkili bir eğitim sürecinin gerçekleştirilmesi açısından önemlidir. Araştırmada özel eğitim gereksinimli çocukların okul öncesi eğitiminde öğretmenlerin karşılaştıkları sorunların ve bu sorunlarla başa çıkma stratejilerinin öğretmen görüşlerine göre incelenmesi amaçlanmıştır. Bu amaca ulaşmak için katılımcılara aşağıdaki sorular yöneltilmiştir.

Öğretmen görüşlerine göre özel eğitim gereksinimli çocukların okul öncesi eğitiminde karşıllaşılan sorunlar nelerdir?

Özel eğitim gereksinimli çocukların okul öncesi eğitiminde karşılaşılan sorunlarla öğretmenlerin başa çıkma stratejileri nelerdir?

\section{Yöntem}

\section{Araştırmanın Modeli}

Özel eğitim gereksinimli çocukların okul öncesi eğitiminde öğretmenlerin karşılaştıkları sorunları ve bu sorunlarla başa çıkma stratejilerini öğretmen görüşlerine göre incelemeyi amaçlayan bu çalışma nitel yöntemle gerçekleştirilmiştir. Araştırmada fenomenolojik desene başvurulmuştur. Bu desende amaç olayları, kişilerin kendine özgü bakış açısıyla nasıl algıladığının ortaya çıkarılmasıdır (Ersoy, 2016). Fenomenolojik desende araştırmada yer alan kişilerin konuya ilişkin deneyimlerinin olması gerekmektedir (Patton, 2002). Araştırmada özel eğitim gereksinimli çocukların okul öncesi eğitiminde karşılaşılan sorunları birebir deneyimleyen öğretmenlerin görüşleri doğrultusunda incelemek amaçlandığından fenomenolojik desen kullanılmıştır. Bu bağlamda mevcut araştırmanın fenomeni özel eğitim gereksinimli çocukların okul öncesi eğitiminde öğretmenlerin karşılaştıkları sorunlar ve bu sorunlarla başa çıkma stratejileridir.

\section{Çalışma Grubu}

Çalışma, Eskişehir ilinde bulunan özel eğitim anaokullarında görev yapan 17 öğretmenle 2021 yılı Nisan- Mayıs aylarında yapılmıştır. Araştırmanın katılımcıları amaçlı örnekleme yöntemlerinden maksimum çeşitlilik örneklemeye uygun belirlenmiştir. Katılımcılara ait bilgiler aşağıdaki tabloda gösterilmiştir.

Tablo- 1: Katılımcı Bilgileri

\begin{tabular}{llllll}
\hline Kod & Cinsiyet & Okul & Katılımcıların branşı & Görev süresi & Mezuniyet \\
\hline Ö 1 & Kadın & Özel Eğitim Anaokulu & Özel Eğitim Öğretmeni & 9 & Lisans \\
\hline Ö 2 & Kadın & Özel Eğitim Anaokulu & Okul Öncesi Öğretmenliği & 14 & Lisansüstü \\
\hline Ö 3 & Erkek & Özel Eğitim Anaokulu & Okul Öncesi Öğretmenliği & 17 & Lisansüstü \\
\hline Ö 4 & Erkek & Özel Eğitim Anaokulu & Özel Eğitim Öğretmeni & 19 & Lisans \\
\hline Ö 5 & Kadın & Özel Eğitim Anaokulu & Özel Eğitim Öğretmeni & 19 & Lisans \\
\hline Ö 6 & Kadın & Özel Eğitim Anaokulu & Okul Öncesi Öğretmenliği & 15 & Lisansüstü \\
\hline
\end{tabular}


Temel Eğitim Dergisi / Journal of Primary Education, 2021, 11, 6-16

\begin{tabular}{llllll}
\hline Ö 7 & Kadın & Özel Eğitim Anaokulu & Özel Eğitim Öğretmeni & 22 & Lisans \\
\hline Ö 8 & Erkek & Özel Eğitim Anaokulu & Özel Eğitim Öğretmeni & 20 & Lisans \\
\hline Ö 9 & Kadın & Özel Eğitim Anaokulu & Özel Eğitim Öğretmeni & 14 & Lisans \\
\hline Ö 10 & Kadın & Özel Eğitim Anaokulu & Okul Öncesi Öğretmenliği & 15 & Lisans \\
\hline Ö 11 & Kadın & Özel Eğitim Anaokulu & Okul Öncesi Öğretmenliği & 18 & Lisans \\
\hline Ö 12 & Kadın & Özel Eğitim Anaokulu & Özel Eğitim Öğretmeni & 17 & Lisansüstü \\
\hline Ö 13 & Erkek & Özel Eğitim Anaokulu & Okul Öncesi Öğretmenliği & 12 & Lisans \\
\hline Ö 14 & Kadın & Özel Eğitim Anaokulu & Özel Eğitim Öğretmeni & 22 & Lisans \\
\hline Ö 15 & Kadın & Özel Eğitim Anaokulu & Özel Eğitim Öğretmeni & 19 & Lisans \\
\hline Ö 16 & Erkek & Özel Eğitim Anaokulu & Okul Öncesi Öğretmenliği & 14 & Lisans \\
\hline Ö 17 & Kadın & Özel Eğitim Anaokulu & Özel Eğitim Öğretmeni & 17 & Lisans \\
\hline
\end{tabular}

\section{Veri Toplama Aracı}

Araştırmada özel eğitim gereksinimli çocukların okul öncesi eğitiminde öğretmenlerin karşılaştıkları sorunları ve bu sorunlarla başa çıkma stratejilerini öğretmen görüşlerine göre incelemek amacıyla özel eğitim anaokullarında görev yapan öğretmenlerle görüşmeler yapılmıştır. Araştırma verilerinin toplanması aşamasında yarı-yapılandııımış görüşme formundan yararlanılmıştır. Form hazırlanırken alanyazın taraması yapılmış ve iki soruluk taslak form hazırlanmıştır. Bu form ilk olarak çeşitli okullarda görevli üç öğretmenle görüşülerek ön uygulama yapılmıştır. Daha sonrasında formdaki sorularla hakkında eğitim bilimleri alanından iki uzmanın görüşü alınmıştır. Uzmanların görüşleri de dikkate alınarak form son halini almıştır.

Katılımcı öğretmenlere, özel eğitim gereksinimli çocukların okul öncesi eğitiminde karşılaştıkları sorunları ve bu sorunlarla başa çıkma stratejilerini ortaya çıkarmak amacıyla şu sorular sorulmuştur.

1. Özel eğitim gereksinimli çocukların okul öncesi eğitiminde karşılaştığınız sorunlar nelerdir?

2.Özel eğitim gereksinimli çocukların okul öncesi eğitiminde karşılaştığınız sorunlarla başa çıkma stratejileriniz nelerdir?

\section{Verilerin Toplanması}

Araştırma kapsamında 2021 yılı Nisan-Mayıs ayları içerisinde verilere ulaşılmıştır. Özel eğitim anaokullarında görev yapmakta olan öğretmenlerle görüşmeler gerçekleştirilmiştir. Görüşme öncesi öğretmenlere araştırma hakkında bilgi verilmiş. Öğretmenlere gizlilik ve güvenirlik konusunda gerekli açıklamalr yapılmıştır. Görüşme süreleri 25-30 dakika sürmüştür. Araştırma öğretmenlere uygun zaman dilimlerinde okullarda gerçekleştirilmiştir.

\section{Verilerin Analizi}

Ulaşılan verilerin analizinde içerik analizi tekniğinden yararlanılmıştır. İçerik analizindeki amaç verilerin kavramlaştıılarak açıklanmasıdır (Yıldırım ve Şimşek, 2016). Bu doğrultuda veriler ayrıntıı olarak incelenmiş, kod ve temalar oluşturulmuştur. Daha sonra veriler literatüre uygun olarak yorumlanmıştır. Bunun yanı sıra iç güvenirliği sağlamak için öğretmenlerden bazılarının görüşlerine yer verilmişitir.

\section{Geçerlik-Güvenirlik Çalışmaları}

Araştırmada öncelikle yazıya aktarılan görüşler katıımcılara gönderilerek kontrol ettirilmiştir. Öğretmenlerin söylemeye çalıştıklarıyla yazıya aktarılan bulgular karşılaştırılarak teyit işlemi gerçekleştirilmiştir. Ardından akran değerlendirmesi oluşturmak amacıyla hazırlanan kod ve temalar ın eğitim bilimleleri alanından iki uzmanın incelemesi sağlanmıştır. Bu uzmanların verdiği geri dönütler ile kodlar tekrar gözden geçirilerek karşılaştırma yapılmıştır. Bu işlem sonucunda iki kod daha eklenerek gerekli kontroller yapılmıştır. Kodlayıcı görüşleri Miles ve Huberman'a (1994) ait güvenirliğin hesaplanması formülüne göre hesaplanmıştır. Buna göre kodlayıcıların uyumu .89 hesaplanmıştır.

\section{Bulgular}


Temel Eğitim Dergisi / Journal of Primary Education, 2021, 11, 6-16

Bu bölümde, özel eğitim gereksinimli çocukların okul öncesi eğitiminde öğretmenlerin karşılaştıkları sorunlara ve bu sorunlarla başa çıkma stratejilerine ilişkin öğretmen görüşlerine yer verilmiştir.

\section{Özel eğitim gereksinimli çocukların okul öncesi eğitiminde öğretmenlerin karşılaştıkları sorunlar}

Öğretmenlerin özel eğitim gereksinimli çocukların okul öncesi eğitiminde karşılaştıkları sorunlara ait görüşleri Tablo 2'de gösterilmiştir.

Tablo-2: Özel Eğitim Gereksinimli Çocukların Okul Öncesi Eğitiminde Karşılaşılan Sorunlar

\begin{tabular}{|c|c|c|}
\hline Tema & Kodlar & Katılımcı Öğretmenler \\
\hline \multirow{7}{*}{$\begin{array}{l}\text { Velilerden } \\
\text { kaynaklı } \\
\text { sorunlar }\end{array}$} & Aile desteğinin yeterli olmaması & $\begin{array}{l}\text { Ö1, Ö2, Ö4, Ö5, Ö6, Ö7, Ö9,Ö10,Ö11, } \\
\text { Ö12, Ö13, Ö15, Ö16, Ö17. }\end{array}$ \\
\hline & $\begin{array}{l}\text { Okulda başlatılan eğitimin evde devamlıı̆̆ının } \\
\text { sağlanamaması }\end{array}$ & $\begin{array}{l}\text { Ö3, Ö5, Ö6, Ö7, Ö9, Ö11, Ö12, Ö14, } \\
\text { Ö15, Ö16, Ö17 }\end{array}$ \\
\hline & $\begin{array}{l}\text { Çocuğun engel durumuyla ilgili ailenin yeterli bilgiye } \\
\text { sahip olmaması }\end{array}$ & $\begin{array}{l}\text { Ö2, Ö4, Ö5, Ö7, Ö8, Ö10, Ö11, Ö12, } \\
\text { Ö16, }\end{array}$ \\
\hline & Ailelerin öğretmenden beklentisinin fazla olması & $\begin{array}{l}\text { Ö1, Ö3, Ö4,Ö6, Ö7, Ö10, Ö11, } \\
\text { Ö13,Ö14, Ö17 }\end{array}$ \\
\hline & Velinin çocuğunun durumunu kabullenmemesi & $\begin{array}{l}\text { Ö2, Ö5, Ö6, Ö7, Ö8, Ö9, Ö10, Ö11, } \\
\text { Ö13, Ö15 }\end{array}$ \\
\hline & Ailelerin sorumluluk bilincinin düşük olması & Ö1, Ö3, Ö4, Ö6, Ö5, Ö9, Ö12, Ö13, Ö16 \\
\hline & $\begin{array}{l}\text { Olumsuz anne, baba tutumları (aşırı koruyucuculuk, } \\
\text { öğretmeni suçlama ve güvenmeme) }\end{array}$ & $\begin{array}{l}\text { Ö1, Ö3, Ö4, Ö6, Ö7, Ö8, Ö10, Ö11, } \\
\text { Ö13, Ö14, Ö15 }\end{array}$ \\
\hline \multirow{3}{*}{$\begin{array}{c}\text { Okulun fiziki } \\
\text { imkânlarından } \\
\text { kaynaklı } \\
\text { sorunlar }\end{array}$} & Çocukların düzeyine uygun yeterli materyal olmayışı & $\begin{array}{l}\text { Ö2, Ö3, Ö4, Ö5, Ö7, Ö8, Ö10, Ö11, } \\
\text { Ö12, Ö16, Ö17 }\end{array}$ \\
\hline & $\begin{array}{l}\text { Sınıf büyüklüklerinin hareket gerektiren etkinlikler } \\
\text { için küçük olması }\end{array}$ & $\begin{array}{l}\text { Ö1, Ö2, Ö3, Ö4,Ö8, Ö9, Ö10, Ö11, } \\
\text { Ö13,Ö14, Ö17 }\end{array}$ \\
\hline & Okul bahçesinin yetersiz olması & $\begin{array}{l}\text { Ö3, Ö4, Ö6, Ö7, Ö9, Ö11, Ö13, Ö14, } \\
\text { Ö15, Ö16, Ö17 }\end{array}$ \\
\hline \multirow{7}{*}{$\begin{array}{l}\text { Öğretim } \\
\text { sürecinde } \\
\text { karşılaşılan } \\
\text { sorunlar }\end{array}$} & Çocukların dikkat süresinin düşük olması & $\begin{array}{l}\text { Ö3, Ö4, Ö6, Ö8, Ö9, Ö11, Ö12, Ö13, } \\
\text { Ö15, Ö16 }\end{array}$ \\
\hline & $\begin{array}{l}\text { Çocukların özbakım becerilerinde çok fazla yardıma } \\
\text { ihtiyaç duyması }\end{array}$ & $\begin{array}{l}\text { Ö2, Ö4, Ö5, Ö6, Ö7, Ö8,Ö10,Ö11, Ö12, } \\
\text { Ö13, Ö15, Ö17 }\end{array}$ \\
\hline & $\begin{array}{l}\text { Konuşma güçlüğü olan çocuklarla iletişim kurmada } \\
\text { zorlanma }\end{array}$ & Ö1, Ö3, Ö5, Ö6, Ö7, Ö8, Ö10, Ö11, Ö14 \\
\hline & Davranış problemlerinin fazla olması & $\begin{array}{l}\text { Ö2, Ö3, Ö5,Ö6, Ö7, Ö10, Ö11, Ö14, } \\
\text { Ö15 }\end{array}$ \\
\hline & Çocukların birbirleriyle uyum sorunu yaşaması & Ö3, Ö5,Ö8, Ö9, Ö10, Ö11, Ö12,Ö14, \\
\hline & Süreçte öğretmen çabasının görülmemesi & Ö2, Ö4, Ö5, Ö6, Ö7, Ö9, Ö13,Ö14, Ö17 \\
\hline & Grup etkinliklerinde zorlanma & Ö4, Ö5, Ö6, Ö7, Ö8, Ö11, Ö13, Ö15 \\
\hline
\end{tabular}

Tablo 2'ye göre özel eğitim gereksinimli çocukların okul öncesi eğitiminde karşılaşılan sorunlara ilişkin öğretmen görüşleri velilerden kaynaklı sorunlar, okulun fiziki imkânlarından kaynaklı sorunlar ve öğretim sürecinde karşılaşılan sorunlar olmak üzere üç temada toplanmıştır.

Velilerden kaynaklı sorunlar teması altında özel eğitim gereksinimli çocukların okul öncesi eğitiminde karşılaşılan sorunlar aile desteğinin yeterli olmaması, okulda başlatılan eğitimin evde devamlılığının sağlanamaması, çocuğun engel durumuyla ilgili ailenin yeterli bilgiye sahip olmaması, ailelerin öğretmenden beklentisinin fazla olması, velinin çocuğunun durumunu kabullenmemesi, ailelerin sorumluluk bilincinin düşük olması ve olumsuz anne, baba tutumları (aşırı koruyucuculuk, öğretmeni suçlama ve güvenmeme) olarak katılımcı öğretmenler tarafından ifade edilmiştir. Bu Iffadeleri destekleyen öğretmen görüşleri aşağıda sunulmuştur. 
Öğretmen olarak veli desteği bizim için çok önemli ilken velilerden yeteri kadar destek görmüyoruz. Okulda başlatılan ve yürütülen eğitimin evde devamlılığı olmuyor. Yoğun ve uzun süreli eğitim alması gereken özel çocuklarda eğitimin bir ayağı aksadığı zaman maalesef yeterli bir verim alınamıyor. Aileler bu konuda tersini iddia etseler de kendilerinin yapması gereken çalışmaları haftada bir ya da iki sefer gittikleri iyileştirme merkezlerinde alınan dersler ile karşıladıklarını düşünüyorlar. Velilerin biz özel çocuk öğretmenlerine köstek değil destek olmalarını umuyorum (Ö7).

Velinin çocuğun düzeyini kabullenmemiş olması, çocukların düzeyine uygun materyallerin eksik olması...(Ö15).

Aile desteği yetersiz, aile eğitimlerine katılım yetersiz, aileler henüz kabullenme aşamasında olduğu için mukavemet var (Ö4).

En çok velilerimle sıkıntı yaşıyorum. Özel çocukların eğitimi konusunda bilgi düzeylerinin düşük olmasına rağmen eğitim sürecinde bizim yaptığımız çalışmalara müdahale edebiliyorlar. Eğitimin öneminin farkında olmalarına rağmen özel çocukların eğitimi konusunda bilgi düzeyleri yetersiz (Ö9).

Okulun fiziki imkânlarından kaynaklı sorunlar teması altında özel eğitim gereksinimli çocukların okul öncesi eğitiminde karşılaşılan sorunlar çocukların düzeyine uygun yeterli materyal olmayışı, sınıf büyüklüklerinin hareket gerektiren etkinlikler için küçük olması ve okul bahçesinin yetersiz olması olarak katılımcı öğretmenler tarafından ifade edilmiştir. Bu İfadeleri destekleyen öğretmen görüşleri aşağıda sunulmuştur.

Tersine kaynaştırma sınıflarında özel eğitim ve okul öncesi öğretmeni olması öğrenciler açısından oldukça verimli olduğunu düşünüyorum. Fakat özel eğitim sınıflarında her iki öğretmenin de özel eğitim branşında olmasının daha verimli olacağı düşüncesindeyim. Özellikle okul öncesi dönemindeki çocukların enerjilerini atabilmeleri için spor aktivitelerini içeren etkinlik, fiziksel alan ve materyal açısından ileri derecede yoksunluk yaşıyoruz. Ayrıca bu alanlarda branş öğretmenleri ile çalışmanın daha verimli olacağı düşüncesindeyim (Ö11).

Dersine girdiğimiz özel çocukların akranları olan diğer çocuklara göre gelişim yönünden önemli dezavantajları oluyor. Ancak okulda bulunan çoğu materyal normal öğrencilere uygun olarak tasarlanmış. Çocuklar bu materyalleri kullanmada zorluk yaşıyor (Ö4).

Ders planlarımıza göre bazı etkinliklerin bahçede yapılması gerekiyor. Bahçenin küçük olması ve gerekli araç-gereçlerin yeterince olmaması çocuklarla yapacağımız etkinlikleri zorlaştırıyor (Ö9).

Öğretim sürecinde karşılaşılan sorunlar teması altında özel eğitim gereksinimli çocukların okul öncesi eğitiminde karşılaşılan sorunlar çocukların dikkat süresinin düşük olması, çocukların özbakım becerilerinde çok fazla yardıma ihtiyaç duyması, konuşma güçlüğü olan çocuklarla iletişim kurmada zorlanma, davranış problemlerinin fazla olması, çocukların birbirleriyle uyum sorunu yaşaması, süreçte öğretmen çabasının görülmemesi ve grup etkinliklerinde zorlanma olarak katılımcı öğretmenler tarafından ifade edilmiştir. Bu İfadeleri destekleyen öğretmen görüşleri aşağıda sunulmuştur.

Öğrencilerimizde dikkat dağınıklığı yüksek düzeyde olması ders işlenişinde zorlanmama neden oluyor. Öz bakım ihtiyaçlarını kendi başlarına karşılayamamaları ve öz bakım gelişimlerinin eksik olması ders esnasında zamanın çoğunun bu ihtiyaçlara gitmesine neden oluyor (Ö14).

Dersine girdiğim çoğu öğrencimin öz bakım becerileri olması gerekenin çok altında. Bu durum ders esnasında büyük sorun oluşturuyor. Ders işlerken bir yandan da elimden geldiği kadar çocukların öz bakımla ilgili ihtiyaçlarını karşılamaya çalışıyorum (Ö6).

Öğrencilerimin birkaç tanesinde ileri derecede konuşma güçlüğü var. Bu sorunu çeşitli çalışmalarla aşmaya çalışıyorum. Fakat çocukların kendini yeterince ifade edememesi öğrenciöğretmen iletişimini zora sokuyor (ö8)

Özel eğitim gereksinimli çocukların okul öncesi eğitiminde öğretmenlerin karşılaştıkları sorunlarla başa çıkma stratejileri

Öğretmenlerin özel eğitim gereksinimli çocukların okul öncesi eğitiminde karşılaştıkları sorunlarla başa çıkma stratejilerine ait görüşleri Tablo 3'de gösterilmiştir.

Tablo-3: Özel Eğitim Gereksinimli Çocukların Okul Öncesi Eğitiminde Öğretmenlerin Karşılaştıkları Sorunlarla Başa Çıkma Stratejilerine İlişkin Görüşleri 
Temel Eğitim Dergisi / Journal of Primary Education, 2021, 11, 6-16

\begin{tabular}{|c|c|c|}
\hline Tema & Kodlar & Katılımcı Öğretmenler \\
\hline \multirow{10}{*}{$\begin{array}{c}\text { Özel Eğitim } \\
\text { Gereksinimli } \\
\text { Çocukların Okul } \\
\text { Öncesi Eğitiminde } \\
\text { Öğretmenlerin } \\
\text { Karşılaştıkları } \\
\text { Sorunlarla Başa } \\
\text { Çıkma Stratejileri }\end{array}$} & Etkili iletişim kurma & $\begin{array}{l}\text { Ö1, Ö2, Ö3, Ö5, Ö6, Ö7, Ö9, Ö10, } \\
\text { Ö11, Ö12, Ö13, Ö15, Ö16, Ö17. }\end{array}$ \\
\hline & $\begin{array}{l}\text { Öz bakım eğitimine daha fazla zaman } \\
\text { ayırma }\end{array}$ & Ö3, Ö5,Ö8, Ö9, Ö10, Ö11, Ö12,Ö14 \\
\hline & Dikkat sürelerini göz önünde & Ö1, Ö3, Ö4, Ö6, Ö7, Ö8, Ö10, Ö11, \\
\hline & bulundurarak etkinlik sürelerini kısa tutma & Ö13, Ö14, Ö15 \\
\hline & ve etkinlikleri çeşitlendirme & \\
\hline & Meslektaşlarla iş birliği yapma & $\begin{array}{l}\text { Ö2, Ö4, Ö5, Ö6, Ö7, Ö8,Ö10,Ö11, } \\
\text { Ö12, Ö13, Ö15, Ö17 }\end{array}$ \\
\hline & İstenmeyen davranışların nedenini tespit & Ö1, Ö3, Ö5, Ö6, Ö7, Ö8, Ö10, Ö11, \\
\hline & etme ve müdahalede bulunma & Ö14 \\
\hline & $\begin{array}{l}\text { Gerekli materyalleri imkânlar dâhilinde } \\
\text { kendi hazırlama }\end{array}$ & $\begin{array}{l}\text { Ö2, Ö3, Ö5,Ö6, Ö7, Ö10, Ö11, Ö14, } \\
\text { Ö15 }\end{array}$ \\
\hline & $\begin{array}{l}\text { Aile eğitimi faaliyetleri düzenleme } \\
\text { Uyum süreçlerini uzun tutma }\end{array}$ & $\begin{array}{l}\text { Ö2, Ö5,Ö6, Ö9, Ö10, Ö11, Ö13, Ö16, } \\
\text { Ö3, Ö5,Ö8, Ö9, Ö10, Ö11, Ö12,Ö14, }\end{array}$ \\
\hline
\end{tabular}

Tablo 3'e göre özel eğitim gereksinimli çocukların okul öncesi eğitiminde öğretmenlerin karşılaştıkları sorunlarla başa çıkma stratejileri etkili iletişim kurma, öz bakım eğitimine daha fazla zaman ayırma, dikkat sürelerini göz önünde bulundurarak etkinlik sürelerini kısa tutma ve etkinlikleri çeşitlendirme, meslektaşlarla iş birliği yapma, istenmeyen davranışların nedenini tespit etme ve müdahalede bulunma, gerekli materyalleri imkânlar dâhilinde kendi hazırlama, aile eğitimi faaliyetleri düzenleme ve uyum süreçlerini uzun tutma olarak sıralanmıştır. Bu bulgulara göre özel eğitim gereksinimli çocukların okul öncesi eğitiminde öğretmenlerin karşılaştıkları sorunlarla başa çıkmada sorunun özelliğine ve nereden kaynaklandığına yönelik kendilerinin çeşitli çözümler ürettiği, öğretmenlerin meslektaş dayanışmasının öneminin farkında oldukları ve ailelerin bilinçlendirilmesine yönelik kendilerinin faaliyetler düzenledikleri anlaşılmaktadır.

Bu ifadeleri destekleyen öğretmen görüşleri aşağıda sunulmuştur.

Aile eğitimi ile birlikte okul ve ev içi kuralları belirliyor, çocuk için çalışmaları ortaklaşa yürütüyoruz. Öz bakım eğitiminde hazır bulunuşluk düzeyine ulaşan çocuklarda tuvalet ve yemek yeme becerilerine öncelik veriyoruz (Ö3).

Dikkat eksikliğinden dolayı odaklamadıkları için etkinlikleri kısa tutup farklı farklı etkinlikler uygulamaya çalışıyorum. Konuşmada sorun yaşayan çocuklar ile okul öncesi eğitimi yapılırken de etkinlikleri mecburen daha uzun sürede uyguluyor, dil gelişimi temelli etkinlikler yapıyorum (Ö6).

Uyum süreçlerini uzun tutmak ve kademeli olarak okulda kalınan süreyi uzatmak. Öncelikli olarak sınıf ortamında oturma süresini uzatmak ve kuralları öğretmek. Ailelere psikolojik destek vermek ve bu süreci sağlıklı olarak geçirmelerini sağlamak için yardımcı oluyoruz (Ö10).

Sürekli aile iletişime geçerek ve eğitim vererek kendi imkânlarımızla materyal hazırlayarak (Ö11).

Kendi imkânlarımızla materyal oluşturup okulun fiziksel alanlarını verimli kullanmaya çalışıyoruz (Ö14).

\section{Tartışma ve Sonuç}

Araştırmada özel eğitim gereksinimli çocukların okul öncesi eğitiminde öğretmenlerin karşılaştıkları sorunlar ve bu sorunlarla başa çıkma stratejileri öğretmen görüşleri doğrultusunda incelenmiştir.

Araştırmada ilk olarak özel eğitim gereksinimli çocukların okul öncesi eğitiminde öğretmenlerin karşılaştıkları sorunlar tespit edilmiştir. Buna göre karşılaşılan sorunlar velilerden kaynaklı sorunlar, okulun fiziki imkânlarından kaynaklı sorunlar ve öğretim sürecinde karşılaşılan sorunlar olmak üzere üç temada toplanmıştır.

Çalışmanın başlıca bulgularından birisi özel eğitim gereksinimli çocukların okul öncesi eğitiminde velilerden kaynaklı sorunlarla karşılaşılmasıdır. Katılımcı öğretmenler aile desteğinin yeterli olmadığını, okulda başlatılan eğitimin evde devamlılı̆ının sağlanamadığını, çocuğun engel durumuyla ilgili ailenin yeterli bilgiye sahip olmadığını, ailelerin öğretmenden beklentisinin fazla olduğunu, velilerin çocuğunun 
durumunu kabullenmediğini, ailelerin sorumluluk bilincinin düşük olduğunu ve olumsuz anne, baba tutumlarıyla (aşırı koruyucuculuk, öğretmeni suçlama ve güvenmeme) karşılaştıklarını ifade etmiştir. Özaydın \& Çolak'ta (2011) yaptıkları çalışmada okulöncesi eğitimde öğretmenlerin karşılaştıkları en önemli sorunun velilerden kaynaklı sorunlar olduğu sonucuna ulaşmıştır. Bağçeli Kahraman, vd. (2018) tarafından yapılana araştırmada da okul öncesinde yaşanan sorunlarla ilgili öğretmenler uyum sürecinde aile faktörünün etkisine dikkati çekmiştir. Can \& Kılıç'ın (2019) yaptıkları araştırmada katııımcı öğretmenler öğrenci ailelerinin desteğinin istenilen düzeyde olmadığı durumlarda çocukların eğitimiyle ilgili süreçte sorunlar meydana geldiğini belirtmiştir. Yapıcı \& Yapıcı (2003) araştırmaları ise veli ilgisizliğinin yaşanılan çeşitli problemlerin nedeni olduğunu, bu durumun da çocuğun eğitim sürecine zarar verdiğini ortaya koymaktadır. Araştırmadaki okulda başlatılan eğitimin evde devamlılığının sağlanamadığı bulgusu Ertör'ün (2015) araştırmasındaki eğitimde sürekliliğin sağlanması için okuldaki eğitim-öğretimin evlerde de sürdürülmesi gerektiğini belirtmektedir. Benzer araştırmalarda da okulda uygulanan etkinlik ve konuların evde desteklenmediği sorunu tespit edimiştir (Zayimoğlu vd., 2016).

Katılımcı öğretmenler özel eğitim gereksinimli çocukların okul öncesi eğitiminde velilerin çocuğunun durumunu kabullenmediği sorunuyla karşılaştıklarını ifade etmişlerdir. Bozarslan \& Batu, (2014) da çalışmasında özel gereksinimli çocukların ailelerinin durumu kabullenmedikleri ve bilgi sahibi olmadıkları sonucuna ulaşmıştır.

Araştırmadaki bir diğer önemli bulgu ise özel eğitim gereksinimli çocukların okul öncesi eğitiminde okulun fiziki imkânlarından kaynaklı sorunlarla karşılaşılmasıdır. Katılımcı öğretmenler bu sorunları çocukların düzeyine uygun yeterli materyal olmayışı, sınıf büyüklüklerinin hareket gerektiren etkinlikler için küçük olması ve okul bahçesinin yetersiz olması olarak ifade etmiştir. Dikici Sığırtmaç vd. nin (2011) yapmış olduğu araştırmada okul öncesi eğitimde öğretmenlerin karşılaştığı sorunların başında fiziki altyapı yetersizliğinden kaynaklı sorunlar yaşandığı bulgusu araştırma bulgularını desteklemektedir. Benzer şekilde Karasu \& Mutlu, (2015) çalışmalarında okul öncesi eğitimde öğretmenlerin sınıf içi malzeme ve donanım sorunuyla karşılaştıkları sonucuna ulaşmıştır. Araştırmadaki sınıf büyüklüklerinin hareket gerektiren etkinlikler için küçük olması bulgusu Karaca \& Aral'ın (2011) araştırmalarındaki okul öncesi eğitim kurumlarındaki dersliklerin yeterli büyüklükte olmadığı, donarım malzemelerinin yetersiz olduğu bulgusunu desteklemektedir. Katılımcı öğretmenler okul bahçelerinin yetersiz olmasına dikkati çekmiştir. Can \& Kılıç'ta (2019) araştırmalarında okul öncesi eğitim kurumlarındaki okul bahçelerinin materyal ve oyuncak bakımından yetersiz olduğu sonucuna ulaşmıştır. Altun \& Gülben'in (2009) araştırmasında da fiziki alt yapı eksikliği ve ders materyallerinin yetersiz olduğu ifade edilmektedir.

Katılımcılar özel eğitim gereksinimli çocukların okul öncesi eğitiminde öğretim sürecinde de sorunlarla karşılaştıklarını belirtmiştir. Bu sorunlar öğrenci çocukların dikkat süresinin düşük olması, çocukların özbakım becerilerinde çok fazla yardıma ihtiyaç duyması, konuşma güçlüğü olan çocuklarla iletişim kurmada zorlanma, davranış problemlerinin fazla olması, çocukların birbirleriyle uyum sorunu yaşaması, süreçte öğretmen çabasının görülmemesi ve grup etkinliklerinde zorlanma olarak ifade edilmiştir. Demir \& Kale, (2019) araştırmalarında özel eğitim gereksinimli öğrencilerin öğretim sürecinde birtakım sorunlarla karşılaşıldığını, özellikle uyum sorunlarının yaşandığını belirtmektedir. Araştırmada katılımcı öğretmenler, öğrencilerdeki davranış problemlerinin fazla olmasından bahsetmiştir. Araştırma bulgusuna paralel olarak Bozarslan \& Batu, (2014) araştırmalarında anaokulundaki davranış problemlerinin fazla olduğu sonucuna ulaşmıştır. Benzer şekilde Bağçeli Kahraman, vd. (2018) tarafından yapılan araştırmada da okul öncesi dönemde öğrencilerde saldırganlık davranışlarıyla karşılaşılabileceği ifade edilmektedir. Karasu \& Mutlu, (2015) çalışmalarında öğretmenlerin özel eğitim gereksinimli öğrencilerin öğretim süreçlerinde sorunlar yaşadığı bulgusu araştırma sonuçlarını desteklemektedir.

Araştırmanın ikinci kategorisi bağlamında özel eğitim gereksinimli çocukların okul öncesi eğitiminde öğretmenlerin karşılaştıkları sorunlarla başa çıkma stratejileri tespit edilmiştir. Buna göre öğretmenlerin karşılaştıkları sorunlarla başa çıkma stratejileri etkili iletişim kurma, öz bakım eğitimine daha fazla zaman ayırma, çocukların dikkat sürelerini göz önünde bulundurarak etkinlik sürelerini kısa tutma ve etkinlikleri çeşitlendirme, meslektaşlarla iş birliği yapma, istenmeyen davranışların nedenini tespit etme ve müdahalede bulunma, gerekli materyalleri imkânlar dâhilinde kendi hazırlama, aile eğitimi faaliyetleri düzenleme ve uyum süreçlerini uzun tutma olarak sıralanmıştır. Katılımcı öğretmenler karşılaştıkları sorunlarla etkili iletişim kurarak başa çıkmaya çalıştıklarını belirtmişlerdir. Alper'e (2007) göre öğretimin etkililiğinin sağlanması için iletişimle ilgili süreçlerin doğru bir şekilde işletilmesi gereklidir. Okulda iletişim süreçlerinin iyileştirilmesiöğretmenlerin iletişim becerisinin geliştirilmesiyle mümkündür. Okul öncesi öğretmenlerinin iletişim becerisinin veliyle kurulan ilişkinin geliştirilmesinde önemli payı vardır (Decker \& Decker, 2005). Öğrencilerin aileleriyle iletişimlerinin sağlanması öğretmenlerin öncelikli sorumluluklarındandır. Çünkü aileyle öğretmenin kurduğu iletişim kalitesi 
öğrenci öğrencnme süreçlerini desteklemekte, iş birliğini geliştirmektedir(Seplocha, 2004). Araştırmada öğretmenler çocukların öz bakım eğitimine daha fazla zaman ayırmaya çalıştıklarını ifade etmişlerdir. Demiriz \& Dinçer'e (2000) göre çocuklara okul öncesinde kazandırılması gereken özbakıma yönelik beceriler, çocuğun gelecekteki yaşamına güven içinde bakılmayı sağlayacaktır. Katılımcı öğretmenler çocukların dikkat sürelerini göz önünde bulundurarak etkinlik sürelerini kısa tuttuklarını ve etkinlikleri çeşitlendirdiklerini belirtmişledir. Varol, Âlâ, \& Eti'ye (2020) göre öğrencilerde dikkat becerisi büyümeyle beraber gelişim göstermektedir. Dikkatin geliştirilmesinde dikkat çalışmalarının yapılması büyük önem taşımaktadır. Öğretmenler özel eğitim gereksinimli çocukların okul öncesi eğitiminde karşılaştıkları sorunlarla meslektaşlarla işbirliği yaparak başa çıktıklarını ifade etmişlerdir. Okulun istenilen amaçlara ulaşmasında öğretmen meslektaş iş birliği son derece önemlidir. Etkili bir eğitim sürecinin gerçekleşmesi için gereken öğretmen niteliklerinden birisi de görevle ilgili faaliyetlerde meslektaş iş birliğin yapılmasıdır (Şişman, 2011). Katılımcı öğretmenler istenmeyen davranışların nedenini tespit ederek müdahalede bulunduklarını ifade etmişlerdir. Sınıf içerisinde olumsuz öğrenci davranışlarıyla baş etmede öncelikle sorunlu davranışın nedeninin tespit edilmesi gerekmektedir. Öğretmenin sınıf içerisinde sorun oluşturan durumları analiz etmesi bu sorunun ortadan kaldırılmasında etkili olacaktır (Kapucuoğlu Tolunay, 2008). Araştırmada öğretmenler aile eğitimi faaliyetleri düzenlemeye çalıştıklarını ifade etmişlerdir. Şahin \& Kalburan, (2009) çalışmasında ailelerin eğitim ihtiyaçlarının belirlenerek karşılanması gerektiğini belirtmektedir. İhtiyaçların tespit edilmesinin sonrasında ailelerle yapılacak eğitim faaliyetlerinin çocukların öğrenme ve eğitim sürecine olumlu yönde katkı yapması beklenmektedir.

Sonuç olarak; özel eğitim gereksinimli çocukların okul öncesi eğitiminde karşılaştıkları sorunların ve bu sorunlarla öğretmenlerin başa çıkma stratejilerinin ortaya çıkarıldığı bu çalışmada, öğretmenlerin velilerden kaynaklı, okulun fiziki imkânlarından kaynaklı ve öğretim sürecinde sorunlar yaşadığı anlaşımaktadır. Bununla birlikte öğretmenlerin bu sorunlarla etkili iletişim kurma, çocukların durumlarını göz önünde bulundurarak hareket etme, meslektaşlarla iş birliği yapma ve ailelere eğitim faaliyeti düzenleyerek başa çıkmaya çalıştıkları anlaşılmaktadır. Araştırma bulgularına dayanarak şu öneriler getirilebilir:

- Özel eğitim gereksinimli çocuğa sahip ailelere eğitim süreçlerindeki rol ve sorumlulukları hakkında bilinçlendirme faaliyetleri yapılabilir.

- Özel eğitim gereksinimli çocukların engel durumlarına uygun okul öncesinde ihtiyaç duyulan ders materyalleri bakanlıkça temin edilmelidir.

- Okul bahçeleri ve sınıfları okul öncesi eğitime uygun olacak şekilde planlanarak yapılmalı, mevcut fiziki mekânlar iyileştirilmelidir.

- Velilerin eğitim sürecinde desteğinin alınmasında okullardaki rehberlik servislerinin etkin rol oynaması sağlanabilir.

- Öğretmenlerin velilerle iş birliğinin geliştirilmesinde okul idareleri eylem planları hazırlayarak faaliyetler yürütebilir.

\section{Kaynakça}

Alper, D. (2007). Psikolojik danışmanlar ve sınıf öğretmenlerinin duygusal zeka düzeyleri - Illetişim ve empati becerilerinin karşılaştııılması. (Yayımlanmamış yüksek lisans tezi), Dokuz Eylül Üniversitesi, İzmir.

Akçamete, A. G. (1998). Türkiye'de Özel Eğitim. S. Eripek (Ed.), Özel eğitim içinde (313-359). Eskişehir: Açıköğretim Fakültesi Yayınları.

Akçamete, A. G., Kayhan, N. \& Şen, M. (2012). Pre-school special education in European union countries and Turkey. Procedia- Socialand Behavioral Sciences, 46(1), 1510-1516.

Altun, T. \& Gülben, A. (2009). Okul öncesinde özel gereksinim duyan çocukların eğitimindeki uygulamalar ve karşılaşılan sorunların öğretmen görüşleri açısından değerlendirilmesi. Ahmet Keleşoğlu Eğitim Fakültesi Dergisi, 28, 253-272.

Bağçeli Kahraman, P., Şen, T., Alataş, S. \& Tütüncü, B. (2018). Okul öncesi dönemde okula uyum sürecine ilişkin öğretmen görüşleri. Abant İzzet Baysal Üniversitesi Eğitim Fakültesi dergisi, 18(2) , 681-701.

Bakkaloğlu, H. (2013). Ebeveynlerin gözüyle özel gereksinimli çocukların erken müdahaleden okul öncesi programlara geçiş süreci. Eğitim ve Bilim, 38(169), 311-327.

Barrafato, A. (1998). Inclusion at the early childhood level: Supports contributing to its success. Canada: Concordia University. 
Başal, M. (2003). Okul öncesi dönemde özel eğitim. S. Eripek (Ed.), Özel eğitim içinde (29-42). Eskişehir: Anadolu Üniversitesi Yayınları.

Başal, H. A. (2013). Okul öncesi eğitime giriş. Bursa: Ekin Yayınları.

Bozarslan, B. \& Batu, E. S. (2014). Özel anaokullarında çalışan eğiticilerin okulöncesi dönemde kaynaştırma ile ilgili görüş ve önerileri. Abant İzzet Baysal Üniversitesi Eğitim Fakültesi Dergisi, 14(2), 86-108.

Büyüköztürk, Ş., Kılıç, E., Akgün, Ö., Karadeniz, Ş. \& Demirel, F. (2014). Bilimsel araştırma yöntemleri (13. baskı). Ankara: Pegem Yayınları.

Can, E, Kılıç, Ş. (2019). Okul öncesi eğitim: Temel sorunlar ve çözüm önerileri. Milli Eğitim Dergisi, 48(1), 483-519.

Cavkaytar, A. (2019). Özel eğitime gereksinim duyan çocuklar ve özel eğitim. İ. H. Diken (Ed.), Özel eğitime gereksinim duyan çocuklar ve özel eğitim içinde (3-29). Ankara: Pegem Akademi Yayınları

Dinç, B. \& İnal, G. (2012). Okul öncesi eğitimde aile katılım çalışmaları. F. Alisinanoğlu(Ed.). Okul öncesi eğitimde özel eğitim yöntemleri içinde (179-216). Ankara: Pegem-Akademi.

Decker, C.A., \& Decker ,J.R. (2005). Planning and administering early childhood programs (8. ed ). Upper Saddle River, NJ: Prentice Hall.11

Demir, S. \& Kale, M., (2019). İlkokullarda özel eğitim sınıflarında karşılaşılan sorunların incelenmesi. Ahi Evran Üniversitesi Kırşehir Eğitim Fakültesi Dergisi, 20(1), 354-373.

Demiriz, S. \& Dinçer, Ç., (2000). Okul öncesi dönem çocuklarının öz bakım becerilerinin annelerinin çalışıp çalışmama durumuna göre incelenmesi. Hacettepe Üniversitesi Eğitim Fakültesi Dergisi, 19(19), 58-65.

Dikici Sığırtmaç, A., Hoş, G. \& Abbak, B. S. (2011). Okul öncesi öğretmenlerinin kaynaştırma eğitiminde yaşanan sorunlara yönelik kullandıkları çözüm yolları ve önerileri. Ahi Evran Üniversitesi Kırşehir Eğitim Fakültesi Dergisi, 12(4), 205-223.

Dinç, B., Güven, G.,İnal, İnan, H. Z., Cevher Kalburan, N., Özbey,S. \& Şimşek, Ö.(2012). Okul öncesi eğitimde özel öğretim yöntemleri.(2. baskı). Ankara: Pegem Akademi.

Ersoy, F. (2016). Eğitimde nitel araştırma desenleri A. Saban ve A. Ersoy (Ed.) Ankara: Anı Yayıncılık.

Ertör, E. (2015). Illkokullarda görev yapan anasınıfı öğretmenlerinin yaşadıkları yönetsel sorunlara ilişkin görüşleri. Yayımlanmamış Yüksek Lisans Tezi, Atatürk Üniversitesi Eğitim Bilimleri Enstitüsü, Erzurum.

Gürkan, T., (2013). Okul öncesi eğitim programı. R. Zembat (Ed.) Okul öncesinde özel öğretim yöntemleri içinde (2979). Ankara: Anı Yayıncılık,

Kapucuoğlu Tolunay, A. (2008). Sınıf öğretmenlerinin sınıfta karşılaştıkları istenmeyen öğrenci davranışları ve bu davranışlara karsı kullandıkları baş etme yöntemleri. . (Yayımlanmamış yüksek lisans tezi), Uludağ Üniversitesi, Bursa.

Karaca, N. H. \& Aral, N. (2011). Okul öncesi öğretmen adaylarının öğretmenlik uygulamalarında karşılaştıkları sorunlar. 2nd International Conference on New Trends in Education and Their Implications, Antalya.

Karasu, T. \& Mutlu, Y. (2015). Öğretmenlerin perspektifinden özel eğitimde yaşanan sorunlar ve çözüm önerileri: Muş ili örneği. Anemon Muş Alparslan Üniversitesi Sosyal Bilimler Dergisi, 2(1) , 47-66.

Kern, M. L. \& Friedman, H. S. (2009). Early educational milestones as predictors of lifelong academic achievement, midlife adjustment and longevity. Journal of Applied Developmental Psychology, 30(4), 419430.

Miles, M. B. \& Huberman, A. M. (1994). An expanded sourcebook qualitative data analysis. California: Sage.

Özaydın, L. \& Çolak, A. (2011). Okul öncesi öğretmenlerinin kaynaştırma eğitimine ve "okul öncesi eğitimde kaynaştırma eğitimi hizmet içi eğitim programına ilişkin görüşleri. Kalem Eğitim ve İnsan Bilimleri Dergisi, 1(1), 189-226.

Patton, M. Q. (2002). Qualitative research \& evaluation methods (3rd ed.). Thousand Oaks, CA: Sage.

Praisner, C.L. (2003). Attitudes of elemantary school principals toward the inclusion of students with disabilities. Council for Exceptional Children, 69(2),135-145.

Ridzwan, S. B. \& Mokhsein, S. E. B. (2017). Creativity in preschool assessment. International Journal of Academic Research in Business and Social Sciences, 7(2), 543-560.

Seplocha, H., (2004). Family ties. partnerships for learning: Conferencing with families. Young Children, 59(5), 9698.

Şahin, E. (2005). Okul öncesi eğitimi öğretmen adayları ve öğretmenleri için uygulama kılavuzu. Ankara: Anı Yayıncılık.

Şahbaz, Ü. \& Kalay, G. (2010). Okulöncesi eğitimi öğretmen adaylarının kaynaştırmaya ilişkin görüşlerinin belirlenmesi. Mehmet Akif Ersoy Üniversitesi Eğitim Fakültesi Dergisi, 19, 116-135. 
Temel Eğitim Dergisi / Journal of Primary Education, 2021, 11, 6-16

Şişman, M. (2011). Eğitimde mükemmellik arayışı etkili okullar. Ankara: PegemA.

Varol, İ, Âlâ, S, \& Eti, M. (2020). Okul öncesi eğitimde türkçe etkinliklerinde kullanılan hikâye anlatım tekniklerinin çocukların dikkat süresi üzerine etkisi. Temel Eğitim, 2(1), 26-39.

Vuran, S. (2013). Özel eğitim. Ankara: Maya Akademi.

Yapıcı, M., \& Yapıcı, G. (2003). İlköğretim öğretmenlerinin karşılaştığı sorunlar. Üniversite ve Toplum, 3(3), 83-98.

Zayimoğlu Öztürk, F, Kaya, N, Durmaz, E. (2016). Okul öncesi öğretmenlerinin görev sürecinde yaşadıkları eğitimsel sorunlar ve çözüm önerileri. Karadeniz Sosyal Bilimler Dergisi, 7(03), 68-94. 